\title{
SCAN RADIO FREKWENSI (RF) DRIVE TEST DALAM TELEKOMUNIKASI
}

\author{
Peniarsih \\ ppeniarsih@yahoo.co.id
}

\begin{abstract}
In order to explore the potential candidates for employment, then in the world of school or college need to conduct scouting systematically between education obtained from any school or college with the business world. This can be realized through practical work so that students will be directed to achieve a professional competence.

Planning is to get the optimal use of resources and maximum revenue potential while maintaining the level of quality of the system. In addition to cost considerations and spectrum allocation should also be considered. A system must be well planned so that when traffic increases, the capacity can be increased. Because the environment in each region is different, so different each macrocell and microcell network. Therefore, accurate planning is essential to ensure that the system can be enhanced capacity and improved network quality.

$R F$ planning has an important role in the design of mobile. With proper growth plan, we can reduce a lot of the problems that may arise and also reduce the cost optimization. However, if planning is bad then it will appear a lot of problems on the network and also increase the cost optimization.
\end{abstract}

Keyword: Scan Radio, Frekwensi. Telekonumikasi

\section{PENDAHULUAN}

\section{Latar Belakang}

Dalam rangka untuk menggali potensi calon tenaga kerja, maka dalam dunia sekolah ataupun perkuliahan perlu mengadakan pemanduan secara sistematis antara pendidikan yang didapat dari bangku sekolah atau pun perkuliahan dengan dunia usaha. Hal ini dapat diwujudkan melalui kegiatan kerja praktek sehingga mahasiswa akan terarah untuk mencapai suatu kompetensi secara profesional.

Perencanaan adalah untuk mendapatkan penggunaan sumber daya yang optimal dan potensi pendapatan maksimum dengan tetap mempertahankan tingkat kualitas sistem. Selain itu pertimbangan biaya dan alokasi spektrum juga harus diperhatikan. Sebuah sistem harus di- rencanakan dengan baik agar saat trafik meningkat maka kapasitasnya dapat ditambah. Karena lingkungan di setiap wilayah berbeda-beda, maka berbeda pula setiap jaringan macrocell dan microcell. Oleh karena itu, perencanaan yang akurat sangat penting untuk memastikan bahwa sistem dapat ditingkatkan kapasitasnya dan diperbaiki kualitas jaringannya.

$R F$ planning memiliki peranan penting dalam desain seluler. Dengan perencanaan pertumbuhan yang tepat, kita dapat mengurangi banyak permasalahan yang mungkin timbul dan juga mengurangi biaya optimisasi. Namun jika perencanaannya buruk maka akan muncul banyak permasalahan pada jaringan dan juga meningkatkan biaya optimisasi. 
Pada saat ini perkembangan dunia teknologi informasi dan telekomunikasi semakin marak, hal ini dapat dilihat tidak hanya pada peralatan telekomunikasi yang beragam, tetapi juga pada teknik pengiriman informasi yang semakin canggih. Perkembangan teknologi ini dapat kita amati mulai dari proses pengumpulan informasi, proses pengolahan informasi maupun proses pendistribusiannya. Hal ini membuktikan bahwa teknologi merupakan jawaban atas keinginan manusia dalam memperoleh berbagai informasi secara menyeluruh dengan cepat, tepat, dan akurat. Kemampuan untuk menangkap maupun menerima, mengolah, dan mentransfer informasi yang berguna dari satu lokasi ke lokasi lainnya melalui jaringan komunikasi merupakan karakteristik dari teknologi informasi saat ini.

\section{Tujuan Dan Manfaat}

1. Menciptakan suatu hubungan yang sinergis, jelas dan terarah antara dunia perguruan tinggi dan dunia kerja.

2. Meningkatkan kepedulian dan partisipasi dunia usaha dalam memberikan kontribusinya pada sistem pendidikan nasional.

3. Membuka wawasan mahasiswa agar dapat mengetahui dan memahami aplikasi ilmunya di dunia industri pada umumnya serta mampu menyerap dan berasosiasi dengan dunia kerja secara utuh.

4. Memahami dan mengetahui sistem kerja di dunia industri sekaligus mampu mengadakan pendekatan masalah secara utuh.

5. Menumbuhkan dan menciptakan pola berpikir konstruktif yang lebih berwawasan bagi mahasiswa.

\section{Metodologi}

Metodologi yang digunakan dalam Penelitian ini dilakukan dengan cara :

1. Studi lapangan.

2. Interview

3. Studi literatur dan mengumpulkan data-data teknis, yang dilakukan dengan cara mempelajari `katalog, serta informasi lain yang dapat dijadikan teori penunjang dalam pembuatan laporan ini.

a. Layanan atau Konsultasi di bidang Telekomunikasi

Network Design dimana didukung oleh tim yang terbukti memiliki keahlian di bidang :

- RF Planning

- Initial Network Design including issued search ring

- Frequency planning

- Transmission Planning

\section{RF Survey}

Candidate selection and assessment

Antenna placement, azimuth, height, mounting and type

Feeder running

Space and power supply availability

\section{Transmission survey}

Line of Sght (LOS) survey

Space of antenna availability

Space of equipment availability

\section{Radio Frequency Interference} (RFI) Scan

Frequency channels availability Existing Frequency interference

Point-to-point scan

Circular scan for green-field

Tools :

Advantest, U3771 Field-use Microwave Spectrum Analyzer with built-in preamp, 
Freq.range: $9 \mathrm{kHz}-31.8 \mathrm{Ghz}$

Schwarzbeck BBHA 9120D

broad-band horn antenna 1-18

Ghz

Global Positioning System (GPS)

$\mathrm{V}$, compass

Laptop

Binoculars

b. Pengembangan Jaringan dan sistem Informasi

○ Installasi, Tes and

Pengawasan

- Installation, Test \& Commissioning BTS

- Installation, Test \& Commissioning

Microwave

- Installation, Test \& Commissioning Fiber Optic

- Installation, Test \& Commissioning Power System

- Installation

Antenna

Cellular and Microwave

- Installation, Test \& Commissioning RF and

- Microwave cables

- Installation of In-building solution system

- Antenna alignment for both RF and Microwave

- Solusi Information System (IS)

- Billing and Customer Care

- E-care

- Billing of interconnection traffic

- Partner Relationship Management

- Business Intelligent

- Fraud Management

- Revenue Assurance

- Mediation
- Access Network Management

- Geographic Information System

- Optimisasi Jaringan

- Network Auditing (Database Hardware and Software)

- Data Collection (Drive Test and Statistic)

- Problem finding and troubleshooting

- Network Benchmarking

- RF Optimization

\section{LANDASAN TEORI}

\subsection{Pengenalan $R F$ Planning}

Tujuan dari perencanaan adalah untuk mendapatkan penggunaan sumber daya yang optimal dan potensi pendapatan maksimum dengan tetap mempertahankan tingkat kualitas sistem. Selain itu pertimbangan biaya dan alokasi spektrum juga harus diperhatikan. Sebuah sistem harus direncanakan dengan baik agar saat trafik meningkat maka kapasitasnya dapat ditambah. Karena lingkungan di setiap wilayah berbedabeda, maka berbeda pula setiap jaringan macrocell dan microcell. Oleh karena itu, perencanaan yang akurat sangat penting untuk memastikan bahwa sistem dapat ditingkatkan kapasitasnya dan diperbaiki kualitas jaringannya.

$R F$ planning memiliki peranan penting dalam desain seluler. Dengan perencanaan pertumbuhan yang tepat, kita dapat mengurangi banyak permasalahan yang mungkin timbul dan juga mengurangi biaya optimisasi. Namun jika perencanaannya buruk maka akan muncul banyak permasalahan pada jaringan dan juga meningkatkan biaya optimisasi. 


\subsection{Peralatan yang Digunakan Dalam RF Planning}

- Network Planning Tool

Ada beberapa macam software yang digunakan dalam membuat perencanaan suatu jaringan telekomunikasi. Contoh software yang sering digunakan adalah Planet (MSI) atau Wizard (Agilent). Software ini berguna untuk melihat hasil simulasi jangkauan perencanaan yang sudah dibuat. Dari software tersebut juga bisa dilihat besar co-channel dan adjacent channel interference yang terjadi. Selain itu, dengan menggunakan software ini maka bisa juga dilakukan perencanaan frekuensi dan kode tiap sel secara otomatis. Cara penggunaan software adalah memasukkan parameter data lokasi site dan informasi peta (kontur dan bangunan). Setelah itu hasil simulasi bisa segera didapatkan. Pada prinsipnya alat bantu (software) ini bisa mengestimasi dengan cukup akurat kuat sinyal pada bagian-bagian wilayah perencanaan.

- CW Propagation Tool

Gambar 3.2 merupakan contoh dari $C W$ propagation tool. Propagation test kit terdiri dari:

- Transmitter.

- Antena (umumnya omni).

- Receiver untuk mendeteksi RSS (Received Signal Levels). Receiver harus dikonfigurasi agar sesuai dengan hukum Lee.

- Laptop untuk mengumpulkan data.

- GPS untuk mengetahui latitude and longitude.

- Kabel and perlengkapannya.

- Wattmeter untuk mengukur VSWR.

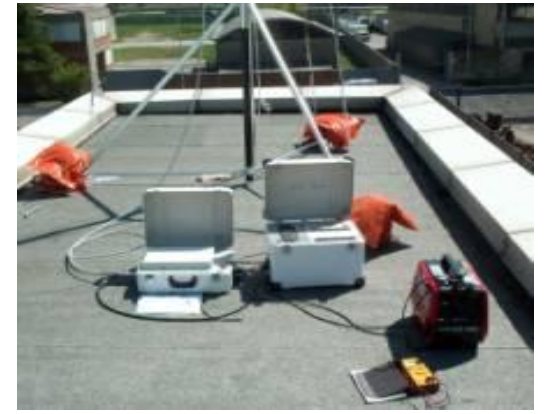

Propagation Tool

- Traffic Modelling Tool

Peralatan ini digunakan untuk pemodelan dan pengukuran jaringan. Peralatan ini membantu untuk menghitung jumlah elemen jaringan untuk memenuhi jangkauan wilayah, kapasitas dan kualitas yang diinginkan. Salah satu contoh Traffic Modelling Tool adalah Netdim.

- Project Management Tool

Project Management Tool berguna dalam menjadwal proses desain RF dan untuk mengetahui sampai mana proyek berjalan. Selain itu juga berfungsi sebagai Inventory Control, Fault Tracking dan juga Finance Management.

\subsection{Pemilihan Site}

Hal pertama yang harus disiapkan adalah menentukan daerah pencarian. Untuk mendapatkan daerah pencarian, latitude dan longitude yang didapat dari planning tool dapat dicari alamatnya dari software mapping. Setelah daerah pencarian ditemukan, selanjutnya adalah memasukkan daerah pencarian tersebut ke dalam project management dengan informasi tambahan seperti radius, tinggi antena, dan lain sebagainya.

Langkah selanjutnya yang harus dilakukan adalah menentukan initial anchor site, dimana hal ini merupakan site penting dalam membangun sebuah 
jaringan telekomunikasi. Contohnya adalah site yang akan bekerja sebagai BSC.

Kemudian data yang ada dimasukkan pada Propagation Tool. Selain itu posisi site juga harus dimasukkan ke Planning Tool dengan tepat beserta perkiraan jangkauan wilayahnya.

Survei lokasi dilakukan dengan mengidentifikasi minimal 3 site dari semua site yang telah direncanakan. Untuk memastikan bahwa kandidat site yang dipilih memiliki jangkauan wilayah yang diharapkan maka drive test perlu dilakukan. Drive test juga menunjukkan kemungkinan masalah interferensi dan handover pada site. Data drive test harus dimasukkan ke Planning Tool untuk dicocokkan dengan prediksi yang ada. Jika tidak cocok (misal $80 \%$ atau $90 \%$ ) maka site tersebut harus segera diperbaiki.

Pada pemilihan site terdapat 2 kriteria yang harus dipenuhi. Kriteria tersebut antara lain :

1. Kriteria radio

Kriteria radio ini merupakan kriteria yang berhubungan dengan propagasi radio. Site yang baik terletak di daerah yang lapang, atau dengan kata lain tidak ada benda di sekitarnya yang memiliki tinggi yang sama dengan tinggi antena. Selain itu antara dua site microwave harus LOS.

2. Kriteria non radio

Kriteria non radio merupakan hal yang berhubungan dengan hal-hal diluar propagasi radio. Misalnya ruang dan tempat untuk meletakkan peralatan. Tersedianya catu daya, biaya sewa tanah yang murah, dan tempat yang terlindungi. Kriteria tersebut harus dipenuhi agar site memiliki kualitas yang baik.

\subsection{Propagasi Gelombang Radio Definisi}

- Isotropic RF Source Merupakan sebuah titik yang menjadi sumber radiasi energi RF seragam ke segala arah.

- Effective Radiated Power (ERP) Daya dipancarkan dari antena half-wave dipole dengan penguatan $0 \mathrm{~dB}$ atau $2.15 \mathrm{dBi}$.

- Effective Isotropic Radiated Power (EIRP)

Daya yang dipancarkan dari sumber isotropic

$\mathrm{EIRP}=\mathrm{ERP}+2.15 \mathrm{~dB}$

- $d B($ decibel)

Merupakan satuan perbedaan atau rasio antara kekuatan daya pancar sinyal. Penamaannya juga untuk mengenang Alexander Graham Bell. Satuan ini digunakan untuk menunjukkan efek dari sebuah perangkat terhadap kekuatan atau daya pancar suatu sinyal.

$$
d B=10 \times \log 10\left(\frac{P_{1}}{P_{2}}\right)
$$

dimana :

$\mathrm{P}_{1}=$ daya referensi

$\mathrm{P}_{2}=$ daya yang dihitung

Besaran $\mathrm{P}_{1}$ dan $\mathrm{P}_{2}$ harus sama.

- $d B m(d B$ miliwatt)

Merupakan satuan kekuatan sinyal atau daya pancar. $0 \mathrm{dbm}$ didefinisikan sebagai $1 \mathrm{~mW}$ (miliWatt) beban daya pancar, contohnya bisa dari sebuah antena ataupun radio. Daya pancar yang kecil merupakan angka negatif (contoh: $-90 \mathrm{dBm}$ ). 


$$
\begin{aligned}
& \mathrm{dBm}=10 \quad \log \quad(\mathrm{P}) \quad(1000 \\
& \mathrm{mW} / \text { watt }) \\
& \text { dimana : } \\
& \mathrm{P}=\text { daya dalam Watt }
\end{aligned}
$$

\subsection{Mekanisme Propagasi}

\section{- Refleksi}

Merupakan sinyal tak langsung yang datang ke receiver. Sinyal tak langsung ini merupakan sinyal hasil pantulan terhadap obyek yang ada di sekitar daerah lintasan. Sinyal hasil refleksi ini akan menyebabkan delay.

- Difraksi

Merupakan mekanisme propagasi dimana sinyal melewati obyek yang cukup besar sehingga seolah-olah menghasilkan sumber sekunder, seperti puncak bukit, gedung, dan lain sebagainya.

- Hamburan

Merupakan mekanisme propagasi dimana sinyal melewati obyek yang kecil maupun obyek kasar sehingga menyebabkan banyak pantulan untuk arah-arah yang berbeda.

\section{Multipath}

Beberapa gelombang yang ditransmisikan akan menyebabkan terjadinya multipath. Karena mekanisme propagasi ini, sinyal yang diterima oleh receiver menjadi banyak. Multipath menyebabkan fluktuasi besar dan cepat dalam sinyal. Fluktuasi ini tidak sama dengan path loss. Multipath menyebabkan perubahan yang cepat pada level sinyal untuk jarak pendek.

\section{Fading}

Fading merupakan karakterisktik utama dalam propagasi radio bergerak. Fading dapat didefinisikan sebagai perubahan fase, polarisasi dan atau level dari suatu sinyal terhadap waktu. Definisi dasar dari fading yang paling umum adalah yang berkaitan dengan mekanisme propagasi yang melibatkan refraksi, refleksi, difraksi, hamburan, dan redaman dari gelombang radio. Pada sistem komunikasi bergerak terdapat dua macam fading yaitu short term fading dan long term fading.

Gambar merupakan gambar yang menunjukkan pengaruh dari fading.

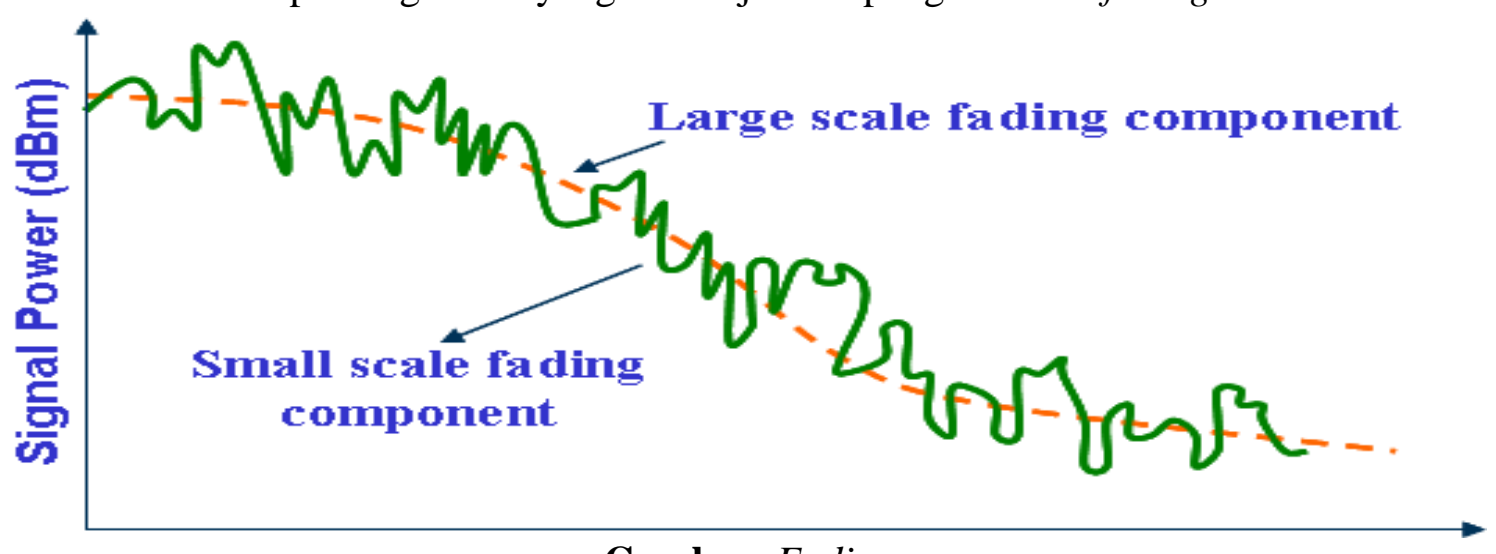

Gambar Fading

- $\quad$ Rayleigh Fading

Pada kanal komunikasi bergerak, distribusi Rayleigh biasa digunakan untuk menjelaskan perubahan waktu dari selubung sinyal fading datar (flat fading) yang diterima, atau selubung 
dari satu komponen multipath. Telah diketahui bahwa selubung dari jumlah antara dua sinyal derau gaussian membentuk distribusi Rayleigh.

- Dopplers Shift

Doppler shift adalah pergeseran frekuensi yang disebabkan pergera- kan penerima. Doppler shift meningkatkan bandwidth sinyal yang ditransmisikan. Misalkan sebuah mobil bergerak pada kecepatan konstan $v$ di sepanjang ruas jalan yang memiliki panjang $d$ antara poin $\mathrm{X}$ dan $\mathrm{Y}$ sewaktu menerima sinyal dari sumber jauh $\mathrm{S}$.

Gambar merupakan ilustrasi dari contoh di atas.

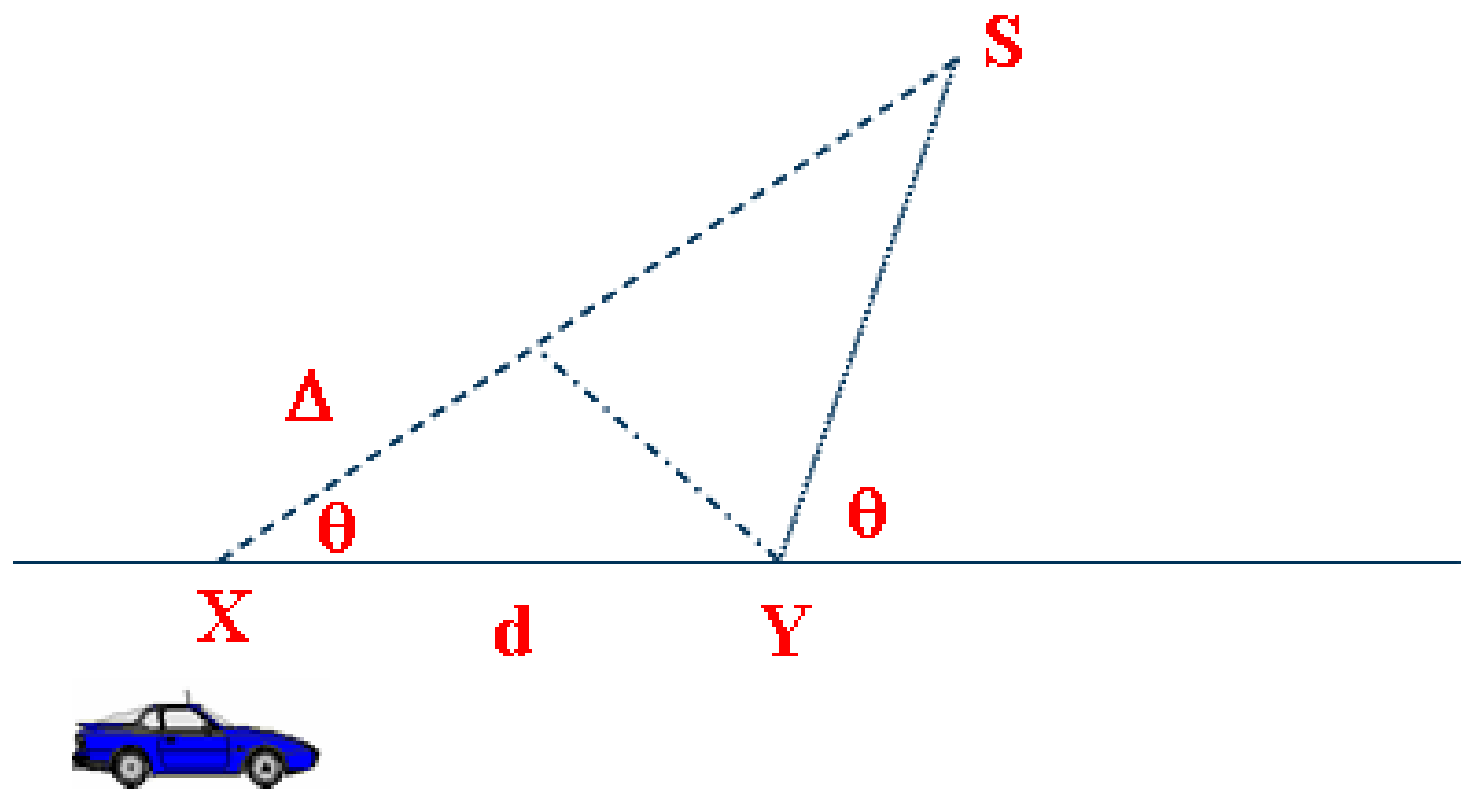

Gambar Dopplers Shift

\section{Penguatan dan Redaman}

Jenis-jenis penguatan :

- Penguatan antena base station

Antena portable mobile phones umumnya memiliki penguatan 0-1 $\mathrm{dBd}$. Sedangkan antena dalam mobil umumnya memiliki penguatan 1-3 $\mathrm{dBd}$.

- Penguatan antena mobile

Antena omni directional umumnya memiliki penguatan 0-9 dBd. Sedangkan antena directional umumnya memiliki penguatan 9-14 $\mathrm{dBd}$.

- Penguatan diversity
Diversity digunakan pada uplink untuk mengatasi multipath fading dengan menggabungkan beberapa sinyal yang tidak berkorelasi. Sistem antena diversity kebanyakan digunakan di BTS pada uplink. Sistem ini dapat direalisasikan dengan memisahkan dua antena penerima atau menggunakan polarisasi diversity. Penguatan diversity juga harus dimasukkan pada perhitungan link budget.

Jenis-jenis Redaman :

- Redaman hardware

- Combiner 
Combiner merupakan alt yang digunakan untuk mentransmisikan beberapa frekuensi berbeda dari satu antena. Ada dua jenis combiner yaitu combiner hybrid dan combiner cavity. Combiner hybrid memiliki dua input dan satu output dengan loss $3 \mathrm{~dB}$. Sedangkan combiner cavity memiliki lima input dan satu output dengan loss 3 $\mathrm{dB}$.

- Kabel

Ada dua kabel yag digunakan yaitu maincable dan jumpercable. Redaman kabel dihitung tiap 100 kaki. Jumpercable memiliki redaman lebih besar dari maincable. Redaman pada kabel juga dipengaruhi oleh frekuensi.

- Konektor

Konektor digunakan untuk menghubungkan komponen-komponen RF dengan redaman sebesar $0.1 \mathrm{~dB}$.

\section{- Duplexer}

Duplexer memungkinkan pengiriman dan penerimaan dari sinyal secara simultan pada antena yang sama. Redaman pada duplexer adalah $0.5 \mathrm{~dB}$ sampai dengan $1 \mathrm{~dB}$. merupakan ilustrasi dari sebuah duplexer.

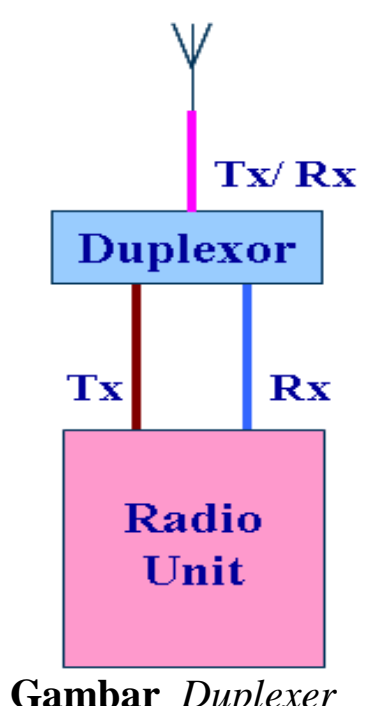

- Body Loss

Hal ini merupakan pengaruh dari redaman dalam uplink dan downlink. Body loss diambil sebesar $2 \mathrm{~dB}$.

- Penetration Loss

Umumnya ada 3 skenario yang dipertimbangkan yaitu di dalam bangunan, mobil dan di jalanan.

\section{Kriteria Sampling}

Ketika mengukur level sinyal RF, kriteria sampling harus dipenuhi untuk menghilangkan komponen short-term fading dan komponen long-term fading. Pengukuran level sinyal RF harus dilakukan melalui $R F$ path atau mobile path pada interval $40 \lambda$ dimana $\lambda$ merupakan panjang gelombang RF. Jumlah pengukuran RF dengan interval $40 \lambda$ harus lebih besar dari 50 . Interval sampling dipilih tergantung pada kecepatan kendaraan selama drive test. Pengukuran harus dihentikan ketika kendaraan berhenti.

Misalkan :

$\mathrm{f}=1900 \mathrm{MHz}$ 
maka :

$$
\begin{aligned}
& \lambda=\frac{3 \times 10^{8}}{1900 \times 10^{6}} \\
& \lambda=0.158 \mathrm{~m}
\end{aligned}
$$

Jadi :

$$
\begin{aligned}
& 40 \lambda=40 \times 0.158 \\
& 40 \lambda=6.32 \mathrm{~m}
\end{aligned}
$$

Dari perhitungan tersebut maka harus dilakukan 50 pengukuran yang dilakukan pada jarak 6.32 meter atau dengan kata lain harus dilakukan pengukuran tiap 0.1264 meter.

\section{Model Ray Tracing}

Ray tracing merupakan salah satu metode yang umum digunakan dalam lingkungan microcellular. Metode ini berjalan dengan menelusuri sinar dari titik transmisi ke titik yang diukur. Ada dua metode pada Ray Tracing yaitu metode Ray Launching dan Mirror Image.

\section{Model Tuning}

Model propagasi menggunakan data clutter dan terrain untuk memprediksi jangkauan wilayah sel pada sebuah site. Namun umumnya data clutter dan terrain pada peta tidak sempurna. Jadi terdapat kemungkinan besar terdapat perbedaan antara jangkauan wilayah sel yang sebenarnya dengan hasil prediksi. Model tuning dilakukan untuk menghindari hal ini. Data untuk model tuning diambil dari data tes propagasi yang dimasukkan dalam planning tool. Dimana data ini menunjukkan kondisi sebenarnya dari jangkauan wilayah sel.

Idealnya jangkauan wilayah sel hasil tes propagasi dan hasil prediksi sama. Dimana pada proses prediksi juga digunakan tipe antena, ketinggian antenna, downtilt, level daya dan parameter lainya yang sama. Jika keduanya tidak sama maka harus dilakukan model tuning dengan mengubah beberapa parameter pada persamaan model propagasi. Setelah keduanya cocok maka proses desain sel telah selesai dengan menggunakan prediksi tersebut.

Idealnya model tuning harus dilakukan untuk setiap site. Namun pada kebanyakan kasus, jaringan dibagi dalam beberapa clutter dan dari masing-masing clutter dilakukan model tuning. Kemudian site dikategorikan dalam masingmasing clutter. Walaupun hal ini tidak sempurna namun hal ini banyak dilakukan oleh operator karena menghemat biaya dan waktu. Proses model tuning ini dilakukan dengan menggunakan Network Planning Tool.

\section{PEMBAHASAN}

\section{PELAKSANAAN DRIVE TEST}

\section{Konsep Drive Test}

Baik operator ataupun vendor pasti melakukan drive test. Operator memerlukan drive test untuk mengoptimalkan kinerja jaringannya. Pelanggan seluler umumnya melihat kinerja layanan jaringan berdasarkan cakupan jaringan dan kualitas panggilan. Perangkat drive test menggunakan handset untuk mensimulasikan masalah yang dialami pelanggan ketika melakukan panggilan.

Sebagai contoh, jika panggilan pelanggan terputus ketika melakukan panggilan dalam keadaan bergerak pada suatu lokasi tertentu, maka perangkat drive test akan mensimulasikan masalah ini dan menyimpan data pada laptop yang terhubung dengan handset. Contoh lain adalah masalah yang dialami pelanggan ketika panggilan diblokir, kualitas suara yang buruk, dan cakupan area pelayanan yang kurang. 
Sistem drive test akan melakukan pengukuran, menyimpan data di laptop, dan menampilkan data menurut waktu dan tempat. Data-data yang diperoleh selama pelaksanaan drive test akan digunakan untuk menganalisa kualitas suatu jaringan seluler.

\section{Peralatan yang Digunakan Saat} Drive Test

Untuk melakukan drive test diperlukan beberapa peralatan yang dibutuhkan, antara lain :

a. Handset TEMS 6.1.4, headset, dan adaptor

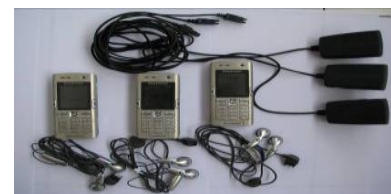

Gambar Handset TEMS 6.1.4.

Pada gambar diperlihatkan contoh dari handset yang sudah terinstal TEMS 6.1.4. Handset TEMS 6.1.4 ini digunakan untuk proses panggilan ke suatu nomor telepon dimana handset ini akan dihubungkan dengan laptop yang sudah terinstal software TEMS 6.1.4.

b. Kabel data handset TEMS 6.1.4

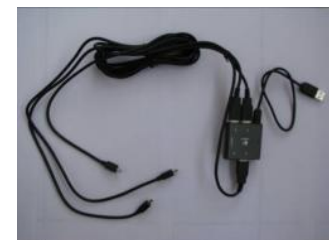

Gambar Kabel data handset TEMS 6.1.4

Kabel data seperti pada gambar digunakan untuk menghubungkan handset TEMS 6.1.4 dengan laptop. c. Laptop dengan TEMS 6.1.4

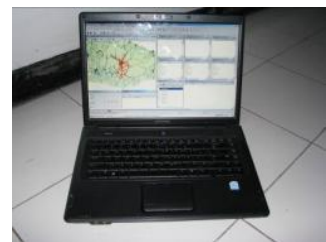

Gambar Laptop dengan software TEMS 6.1 .4

Laptop yang dipakai harus sudah terinstal software TEMS 6.1.4. Laptop ini akan digunakan untuk menyimpan data-data yang diambil pada saat drive test.

d. Adaptor laptop

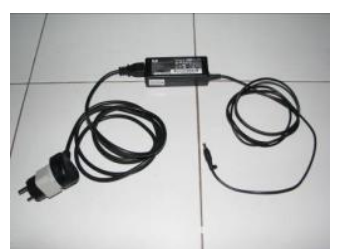

\section{Gambar Adaptor laptop}

Pelaksanaan drive test membutuhkan waktu yang cukup lama. Jadi agar laptop bisa bertahan selama pelaksanaan drive test, diperlukan adaptor laptop yang akan dihubungkan ke koverter DC to AC pada mobil.

e. GPS, antena eksternal, dan kabel data

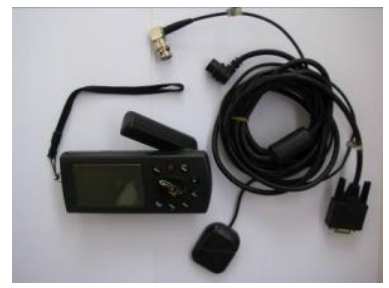

Gambar GPS, antena eksternal, kabel data

Untuk mengetahui keberadaan handset maka diperlukan GPS. Agar 
sinyal yang diterima oleh GPS memiliki kualitas yang baik maka GPS ini dihubungkan dengan suatu antena eksternal. Selain itu, GPS dihubungkan dengan laptop menggunakan kabel data yang tersedia.

\section{f. ATEN / konverter serial to USB}

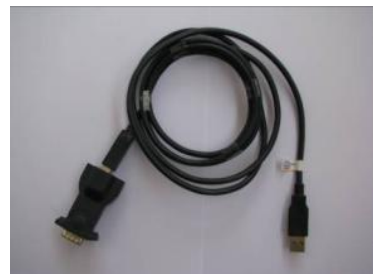

Gambar ATEN

Kabel data yang terhubung dengan GPS memiliki port serial. Sedangkan pada laptop tidak tersedia port serial, yang tersedia hanya port USB. Dengan demikian diperlukan konverter serial to USB.

g. Scanner, antena eksternal RF dan GPS, dan kabel data

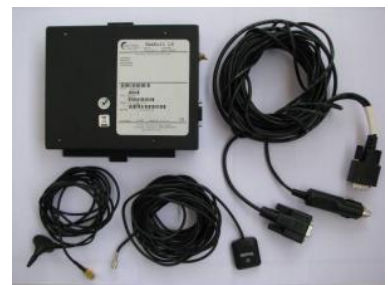

Gambar Scanner, antena eksternal, kabel data

Untuk drive test 3G, diperlukan sebuah scanner untuk mendeteksi sinyal 3G. Disini akan digunakan scanner SeeGull LX WCDMA with GPS. Scanner ini dilengkapi dengan antena eksternal sehingga scanner dapat mendeteksi sinyal dengan baik. h. Konverter DC to AC

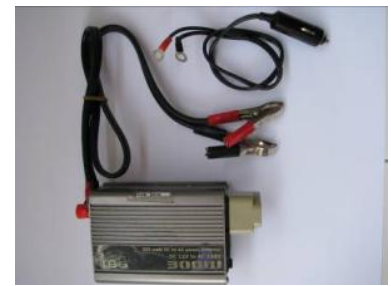

\section{Gambar 4.2.8 Konverter DC to AC}

Untuk catu daya semua peralatan di atas diperlukan arus AC, sedangkan yang tersedia di mobil hanyalah arus DC. Dengan demikian diperlukan suatu konverter DC to AC.

\section{Persiapan Sebelum Memulai Drive Test}

Pelaksanaan drive test membutuhkan waktu yang cukup lama, oleh karena itu sebelum memulai drive test harus disiapkan terlebih dahulu mengenai hal-hal yang berhubungan dengan pelaksanaan drive test.

Yang harus dipersiapkan adalah pengaturan letak semua peralatan di dalam mobil. Semua peralatan harus diletakkan sebaik mungkin tanpa mengganggu kenyamanan pelaksana drive test. Selain itu semua peralatan harus diletakkan pada tempat yang mudah dijangkau sehingga mudah untuk dikonfigurasi. Contoh dari pengaturan letak peralatan dapat dilihat pada gamber

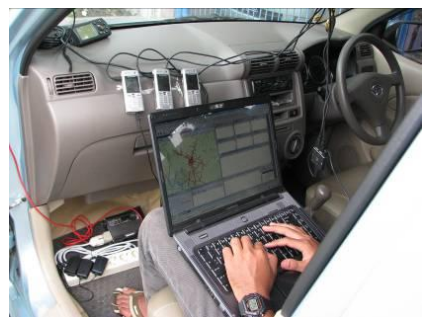

Gambar Pengaturan letak peralatan 
Handset memiliki peran yang sangat penting dalam pelaksanaan drive test. Handset harus diletakkan pada tempat yang yang dapat menerima sinyal dengan baik. Selain itu handset harus diletakkan pada tempat yang dapat dimonitor dengan mudah. Dengan demikian bila sewaktuwaktu terjadi masalah dengan handset, pelaksana drive test dapat mengetahui dengan cepat.

Selain masalah pengaturan letak peralatan drive test, yang harus diperhatikan adalah konfigurasi laptop yang digunakan. Yang harus dikonfigurasi antara lain power management dan virtual memory.

Agar laptop dapat menyala terus selama pelaksanaan drive test, maka pengaturan power management harus diganti seperti gambar

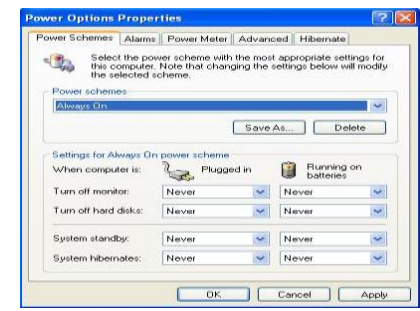

Gambar Power Management

Selain itu yang harus diatur adalah virtual memory pada laptop. Pengaturan ini diperlukan agar laptop memiliki memory yang cukup selama pelaksanaan drive test. Contoh pengaturan virtual memory dapat dilihat pada gambar

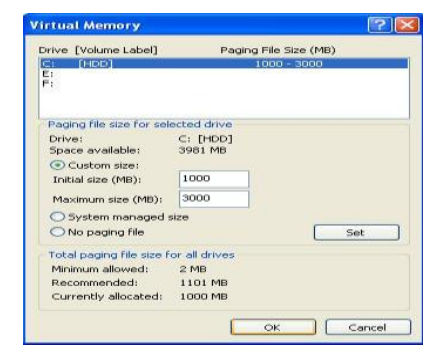

Gambar Virtual Memory

\section{Konfigurasi Port}

Untuk menghubungkan handset dan GPS ke laptop, maka pelaksana drive test harus mengkonfigurasi port yang digunakan pada laptop. Konfigurasi ini harus benar-benar teliti karena jika sampai terjadi kesalahan maka peralatan handset dan GPS tidak akan terdeteksi oleh software TEMS 6.1.4.

Proses penambahan port pada software TEMS 6.1.4 harus dilakukan satu-persatu. Langkah-langkahnya adalah sebagai berikut :

1. Hubungkan handset ke laptop menggunakan kabel data yang tersedia.

2. Pada workspace terdapat tampilan port configuration. Klik add equipment. Setelah itu akan muncul tampilan seperti pada gambar 

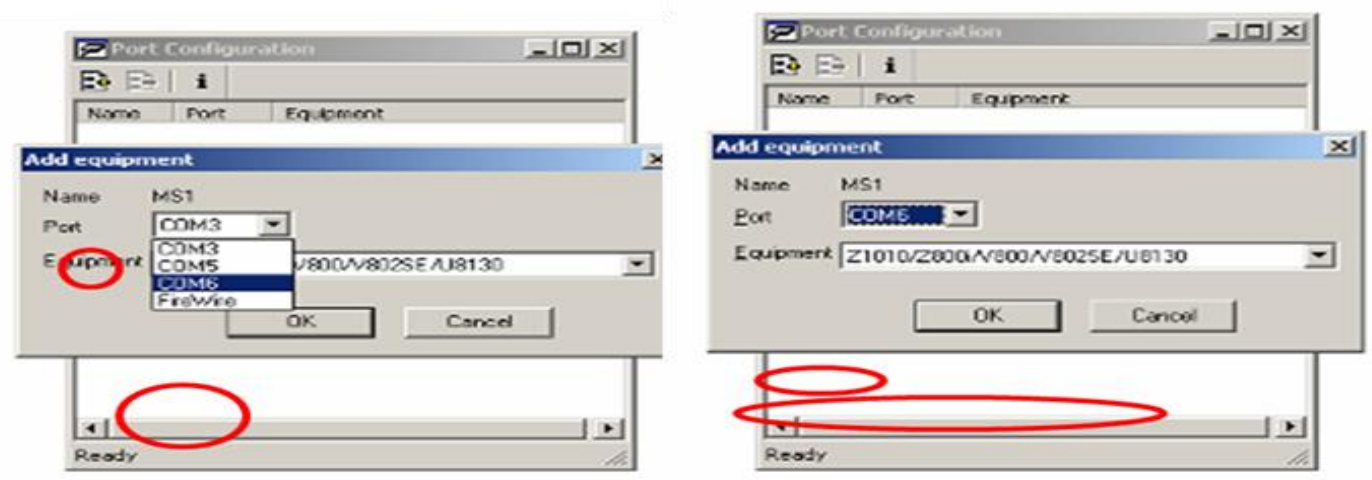

Gambar Konfigurasi Port Handset

3. Pada kolom port akan muncul dua angka port yang berdekatan. Port yang memiliki nilai lebih besar digunakan untuk handset. Dan port yang memiliki nilai lebih kecil digunakan untuk kabel data.
4. Bila menggunakan dua handset, maka caranya sama seperti langkah 1-3.

5. Setelah itu hubungkan GPS ke laptop.

6. Klik add equipment. Setelah itu akan muncul tampilan seperti pada gambar
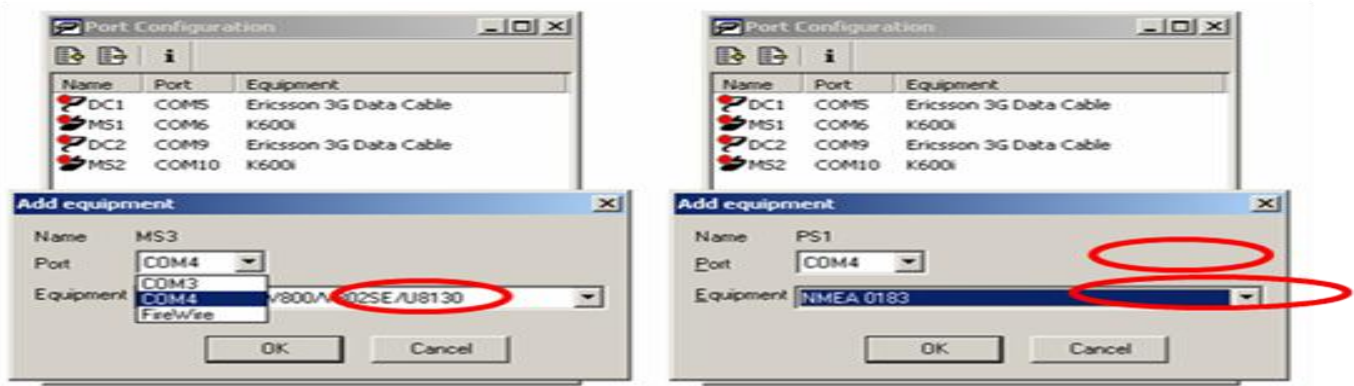

Gambar 4.4.4 Konfigurasi Port GPS

7. Pada kolom port akan muncul satu angka port yang baru. Port ini dipilih dan digunakan untuk GPS. Pada equipment pilih NMEA 0183.
8. Setelah semua peralatan terhubung maka pada workspace bagian port configuration akan muncul tampilan seperti gambar

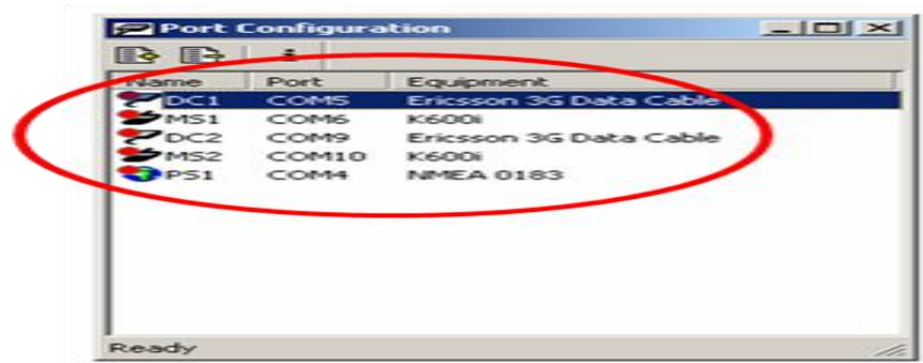

Gambar Port Configuration 
9. Setelah semua peralatan terlihat pada port configuration, klik "connect all" atau tekan F2 pada keyboard. Langkah ini digunakan untuk menghubungkan semua peralatan dengan software TEMS 6.1.4. Jika konfigurasi port dilakukan dengan benar, maka peralatan yang aktif akan ditandai dengan warna hijau. Selain itu jendela GPS, current channel, dan events akan terisi dengan otomatis. Tampilan ini dapat dilihat pada gambar

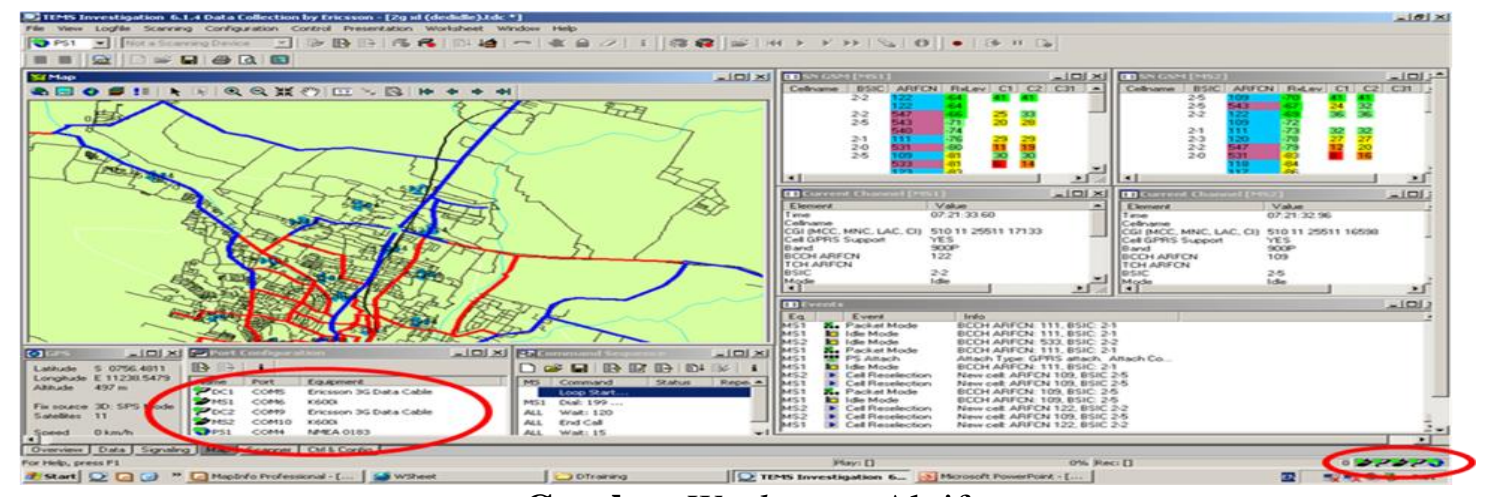

Gambar Workspace Aktif

\section{Konfigurasi Command Sequence}

Pada pelaksanaan drive test disimulasikan proses panggilan ke suatu nomor tertentu. Panggilan ini dilakukan berulang-ulang di setiap tempat yang ingin diuji. Pada software TEMS 6.1.4 proses panggilan ini diatur pada jendela command sequence.

Dalam konfigurasi command sequence terdapat banyak sekali pilihanpilihan yang dapat digunakan. Gambar merupakan contoh dari konfigurasi command sequence.

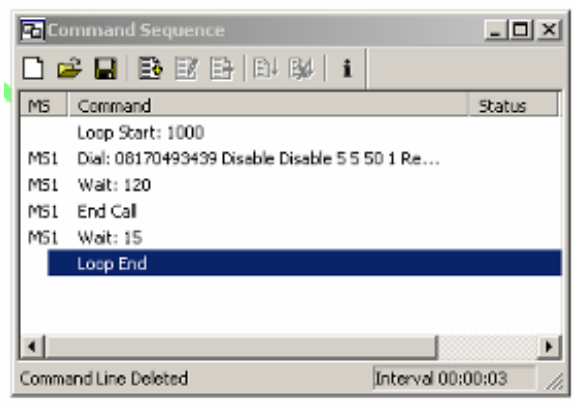

Gambar Command Sequence
Pada gambar terlihat baris pertama adalah "Loop Start : 1000". Hal ini artinya proses panggilan diulang sebanyak 1000 kali. Baris kedua adalah "Dial 081xxxx". Hal ini berarti handset yang terhubung dengan laptop akan melakukan panggilan ke nomor 081xxxxx. Baris ketiga adalah "Wait : 120". Hal ini berarti proses panggilan dilakukan selama 120 detik. Lalu baris keempat adalah "Wait : 15". Baris keempat ini berarti setelah melakukan panggilan selama 120 detik, maka handset akan menunggu selama 15 detik. Setelah menunggu selama 15 detik, lalu dilanjutkan ke baris kelima, yaitu "Loop End" yang berarti menandakan berakhirnya perintah pada command sequence. Prosedur panggilan seperti di atas akan terus berulang sampai 1000 kali.

\section{Konfigurasi Map, Route, dan Cellfile}

Pada software TEMS 6.1.4 terdapat tampilan peta yang akan menunjukkan dimana kita berada. Untuk menghindari proses konfigurasi map berulang-ulang, 
maka proses konfigurasi dilakukan dengan cara membuat "geoset". Langkahlangkah membuat geoset adalah sebagai berikut :

1. Klik "Geoset Manager".

2. Pada jendela geoset manager, klik "Layer Control".

3. Pada layer control, klik add. Lalu akan muncul jendela yang menunjukkan letak map dan route.

4. Pilih map dan route yang akan digunakan.
5. Setelah muncul map dan route yang diinginkan, simpan geoset tersebut.

Setelah selesai menyimpan geoset ke dalam hard disk laptop, maka geoset tersebut dapat digunakan sewaktu-waktu. Untuk menggunakan geoset tersebut, klik "Open Map" pada jendela Map. Setelah itu pilih geoset yang sudah dibuat sebelumnya. Bila proses ini berhasil, maka tampilan peta adalah seperti gambar

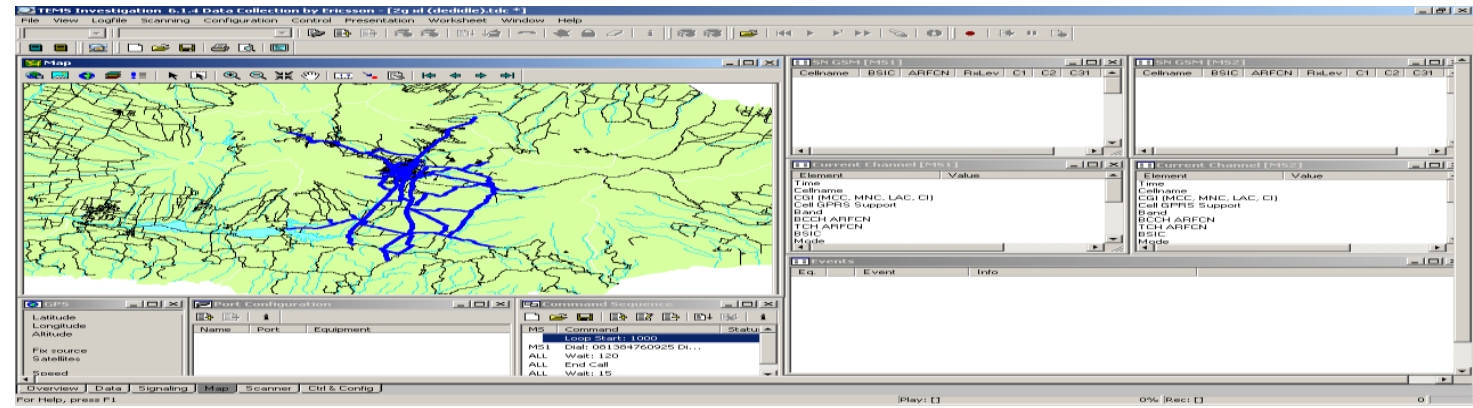

Gambar Geoset

Setelah selesai mengkonfigurasi Map pada TEMS 6.1.4, selanjutnya yang harus dikonfigurasi adalah cellfile. Untuk mengkonfigurasi cellfile, tampilkan jendela "Navigator". Pada jendela navigator terdapat menu General, lalu terdapat sub menu Cellfile Load. Setelah berhasil memasukkan cellfile ke dalam TEMS 6.1.4, maka tampilan pada jendela Map akan berubah seperti gambar

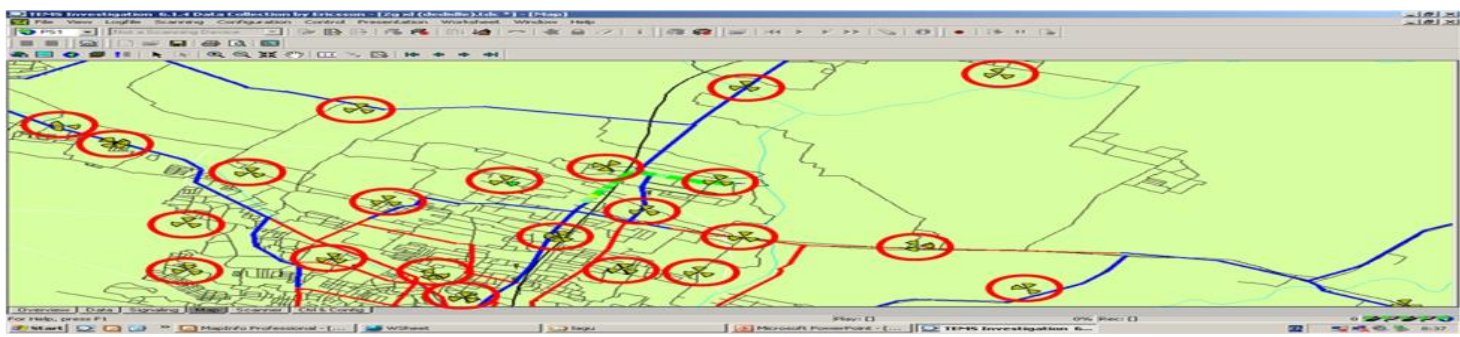

Gambar Cellfile

Dengan adanya cellfile, maka pada jendela Map akan ditampilkan posisi site beserta arah antena sektoral di setiap site.

\section{Memulai Drive Test}

Sebelum memulai drive test, hal-hal yang dijelaskan harus dilakukan dengan baik dan benar, setelah semua persiapan selesai, yaitu pengaturan letak peralatan yang digunakan dan konfigurasi TEMS 6.1.4, maka langkah selanjutnya adalah pelaksanaan drive test di lapangan. Pelaksanaan drive test dilakukan sesuai dengan rute yang telah ditentukan sebelumnya. 
Untuk mengambil data di lapangan, mobil yang dikendarai sebaiknya tidak berjalan terlalu cepat. Kecepatan maksimum yang paling optimal adalah sekitar $40 \mathrm{~km} / \mathrm{jam}$. Hal ini dimaksudkan agar proses pengambilan data dapat dilakukan secara terperinci pada setiap titik sampling.
Untuk memulai drive test, pertama klik "Start Recording" setelah itu baru klik "Start" pada jendela command sequence. Tampilannya dapat dilihat pada gambar

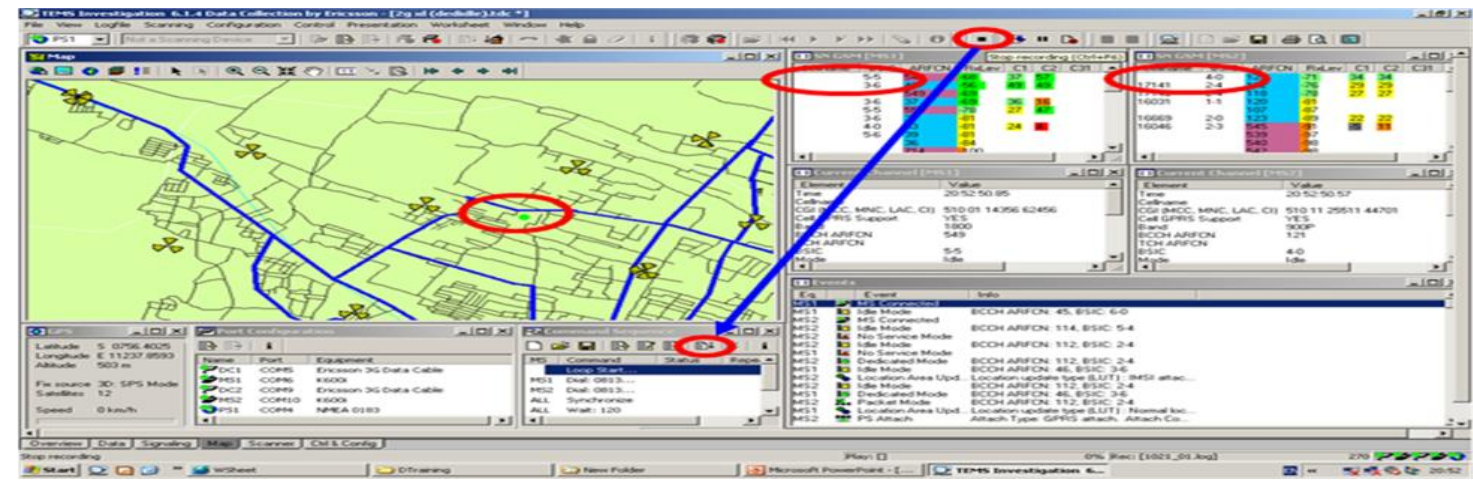

Gambar Memulai Drive Test

Setelah proses panggilan dimulai, yang perlu diperhatikan adalah jendela events. Pada jendela events terlihat semua hal yang terjadi pada saat proses panggilan berlangsung, contohnya adalah proses handover, droped call, blocked call, call establish, dan lain sebagainya.

Selain jendela events, jendela-jendela yang lain juga sangat bermanfaat. Dengan semua data yang ada dapat diketahui berapa $R x$ level, $R x$ Qual, dan lain sebagainya. Pada jendela SN GSM terdapat tab ARFCN (Absolute Radio Frequency Channel Number). Dari data ini dapat diketahui pada saat itu berapakah frekuensi yang digunakan oleh handset. Di sebelahnya ada tab Rx level, dimana pada tab ini dapat diketahui berapakah level sinyal yang sedang diterima oleh handset. Level sinyal ini dinyatakan dalam angka dan warna yang menggambarkan kualitas level sinyal yang diterima.
Sedangkan pada jendela Current Channel terdapat data CGI yang terdiri dari MCC (Mobile Country Code), MNC (Mobile Network Code), LAC (Local Area Code), dan CI (Cell ID). Untuk Indonesia MNC yang digunakan adalah 510. Untuk MNC nilainya berbeda-beda untuk tiap operator telekomunikasi. LAC adalah kode daerah yang ditentukan oleh masing-masing operator, dimana tiap daerah memiliki LAC yang berbedabeda. Sedangkan CI adalah identitas dari setiap cell yang sedang berkomunikasi dengan handset. Pada CI juga dapat diketahui antena sektoral manakah yang sedang melayani handset yang digunakan untuk melakukan panggilan. Hal tersebut dapat dilihat pada angka terakhir CI. Contoh bila CI bernilai 60201, maka yang sedang melayani handset adalah antena sektor 1. Bila CI bernilai 60202, maka yang sedang melayani handset adalah antena sektor 2 . 
Pada jendela Current Channel juga terdapat data TA (Timing Advance), dimana data ini merupakan waktu yang dibutuhkan untuk berkomunikasi antara BTS dan handset. Dari data ini dapat diketahui berapakah jarak antara handset dengan BTS. Contoh bila TA bernilai 4, maka jarak antara handset dengan BTS adalah $2 \mathrm{Km}$.

\section{BCCH (Broadcast Control Channel)} menggambarkan frekuensi yang digunakan dalam sistem GSM untuk downlink dari BTS ke handset. Alokasi spektrum frekuensi untuk GSM awalnya dilakukan pada tahun 1979. Spektrum GSM 900 terdiri atas dua buah sub-band masing-masing sebesar $25 \mathrm{MHz}$, antara $890 \mathrm{MHz}-915 \mathrm{MHz}$ dan $935 \mathrm{MHz}-$ $960 \mathrm{MHz}$. Sebuah sub-band dialokasikan untuk frekuensi uplink dan sub-band yang lain sebagai frekuensi downlink.

Karena konsekuensi logis dari kenaikan redaman atas kenaikan frekuensi, biasanya sub-band terendah dipakai untuk uplink, agar daya yang ditransmisikan handset ke BTS tidak perlu besar.

Kemudian kedua sub-band tersebut dibagi lagi menjadi kanal-kanal, sebuah kanal pada satu sub-band memiliki pasangan dengan sebuah kanal pada $s u b$ band yang lain. Tiap sub-band dibagi menjadi 124 kanal, yang kemudian masing-masing diberi nomor yang dikenal sebagai ARFCN. Jadi sebuah handset yang dialokasikan pada sebuah ARFCN akan beroperasi pada satu frekuensi untuk mengirim dan satu frekuensi untuk menerima sinyal.

Untuk GSM, jarak antar pasangan dengan ARFCN sama selalu $45 \mathrm{MHz}$, dan bandwidth tiap kanal sebesar 200 $\mathrm{kHz}$. Kanal pada tiap awal sub-band digunakan sebagai guard band. Kanal sebanyak 124 inilah yang nantinya dibagi-bagi buat operator-operator GSM yang ada di suatu negara.

Untuk GSM 1800 atau yang biasa dikenal dengan DCS 1800, spektrum frekuensi terletak antara $1710 \mathrm{MHz}-$ $1785 \mathrm{MHz}$ untuk uplink dan $1805 \mathrm{MHz}-$ $1880 \mathrm{MHz}$ untuk downlink. Teknik ini menyediakan 374 ARFCN dengan pemisahan frekuensi sebesar $95 \mathrm{MHz}$ antara uplink dan downlink.

Bila sewaktu-waktu pelaksana drive test ingin berhenti mengambil data di lapangan, maka yang harus dilakukan adalah menghentikan proses panggilan dan menghentikan proses recording. Bila ingin menghentikan, pertama klik "Stop" pada command sequence. Lalu klik "Stop Recording". Tampilannya adalah seperti pada gambar

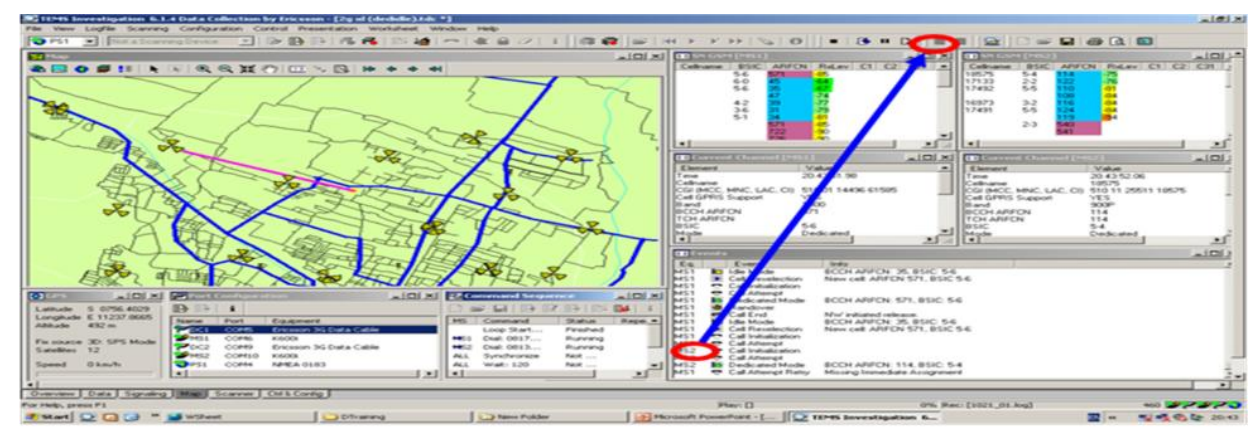

Gambar Stop Recording 
Setelah semua rute yang ditentukan telah dilewati, maka pelaksanaan drive test telah selesai. Langkah selanjutnya yang harus dilakukan adalah mengekspor logfile ke Mapinfo Tab-File.

\section{Post Processing}

Post processing ini adalah proses tahap akhir yang harus dilakukan oleh pelaksana drive test. Pada proses tahap akhir ini logfile selama pelaksanaan drive test akan di plot ke dalam software Mapinfo. Proses ini dilakukan untuk mendapatkan hasil dari logfile agar bisa dilakukan analisa lebih lanjut mengenai kualitas jaringan.

Agar logfile dapat di plot ke dalam Mapinfo, maka logfile tersebut harus diekspor ke Mapinfo Tab-File. Langkahlangkahnya adalah sebagai berikut :

1. Pada software TEMS 6.1.4 terdapat menu logfile, pada menu tersebut klik "Export Logfile".

2. Klik menu "Setup" dan pilih "info element" apa saja yang dibutuhkan. Pilihan info element terlihat pada gambar

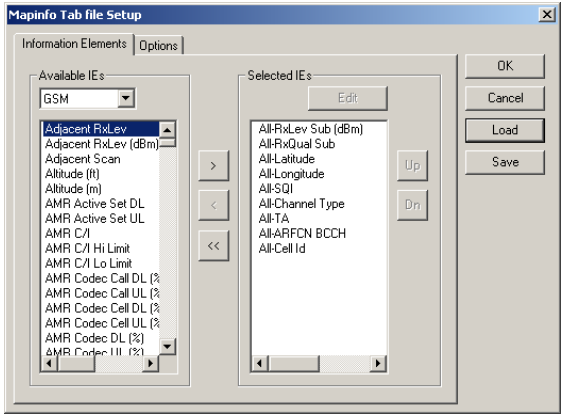

Gambar Info Element
3. Setelah itu pilih logfile mana saja yang akan diekspor.

4. Bila terdapat lebih dari satu logfile, maka pilih "Merge Output" agar hasil plot menjadi satu file saja.

5. Setelah proses ekspor logfile selesai, maka akan keluar tulisan yang menandakan bahwa proses ekspor telah sukses dilaksanakan. Tampilan terlihat seperti pada gambar 4.6.2.

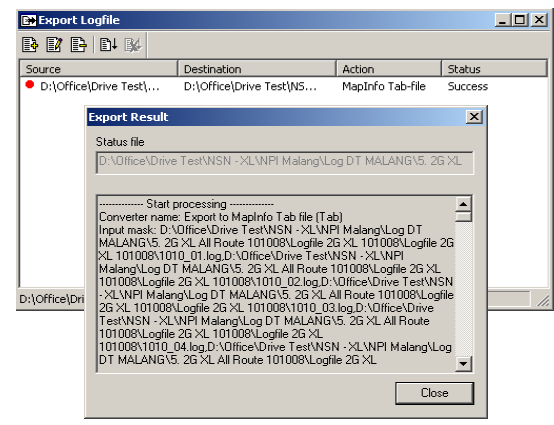

Gambar Ekspor Sukses

Setelah proses ekspor ke dalam Mapinfo Tab-File selesai, maka selanjutnya adalah memasukkan file tersebut ke dalam software Mapinfo. Pada software Mapinfo dapat ditampilkan berbagai macam peta. Pada post processing kali ini, yang akan ditampilkan adalah peta Indonesia, peta jalan di Indonesia, rute pada saat drive test dilakukan, dan data BTS yang terdapat pada daerah tersebut. Hasil dari peta yang ditampilkan terlihat pada gambar. 


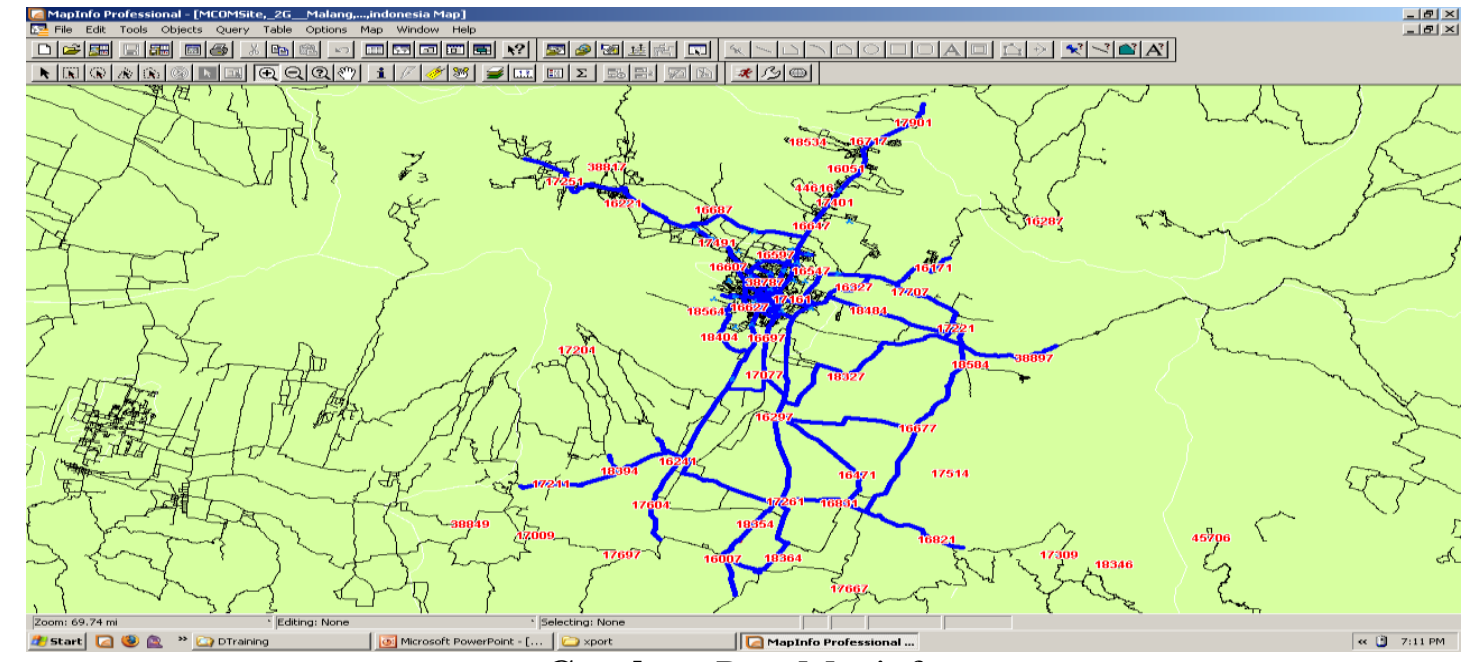

Gambar Peta Mapinfo

Setelah peta pada Mapinfo sudah dikonfigurasi seperti gambar selanjutnya adalah memasukkan data dari logfile yang telah diekspor ke Mapinfo Tab-File. Setelah data tersebut dimasukkan, maka tampilannya adalah seperti pada gambar

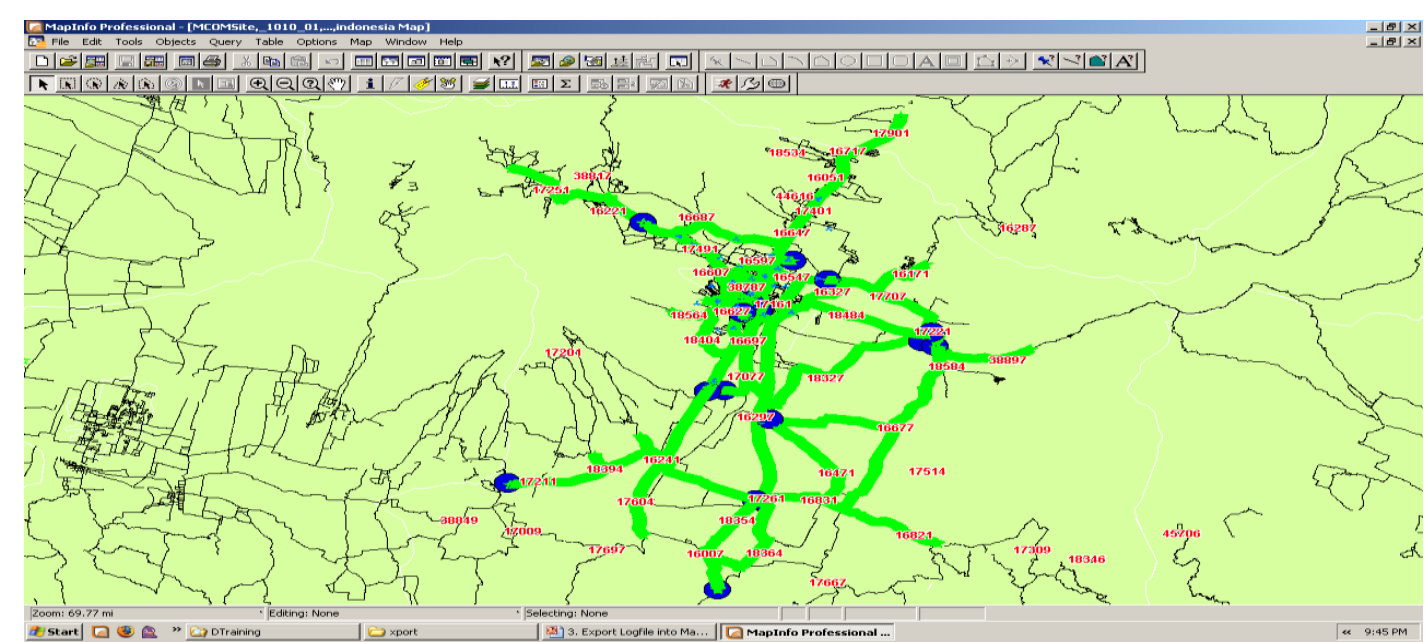

Gambar Peta Mapinfo dan Logfile

Pada software TEMS 6.1.4 data-data yang diperoleh, seperti coverage, $\mathrm{Rx}$ level, dan lain sebagainya diperlihatkan dalam bentuk tulisan. Jadi pada software TEMS 6.1.4 data-data tersebut berupa angka-angka yang berubah setiap saat. Untuk memudahkan analisa kualitas jaringan, maka data-data tersebut dapat diubah atau diperlihatkan dalam bentuk gambar. Caranya adalah dengan membuat "Thematic Map" pada software Mapinfo.
Untuk membuat suatu thematic map, langkah-langkah yang harus dilakukan adalah sebagai berikut :

1. Pada software Mapinfo, klik menu MAP, lalu pilih Create Thematic MAP.

2. Tahap pertama adalah memilih "template" pada menu "Ranges". Contohnya terlihat pada gambar 


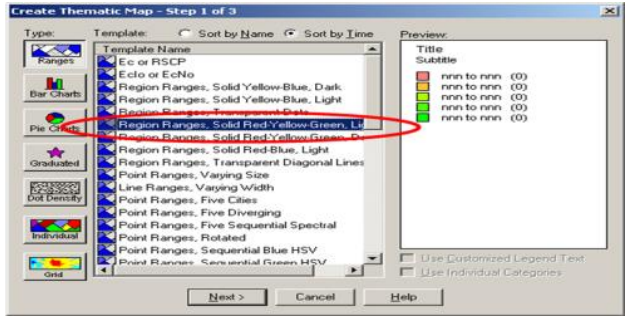

Gambar Ranges

3. Setelah itu tahap kedua adalah memilih file mana yang akan di plot. Selain itu memilih data apakah yang akan di plot. Gambar menunjukkan data yang akan di plot adalah data $R x$ level.

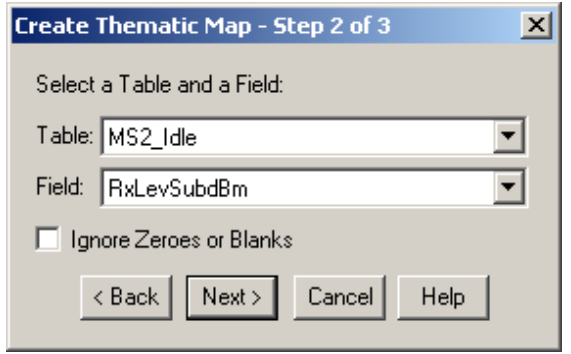

Gambar Thematic Map Tahap Dua
4. Setelah memilih file dan data yang akan di plot, tahap selanjutnya adalah mengatur "legenda" dari hasil plot tersebut. Pada legenda ini dapat ditampilkan rentang suatu nilai dari data yang di plot. Gambar memperlihatkan tahap ketiga dalam proses pembuatan thematic map.

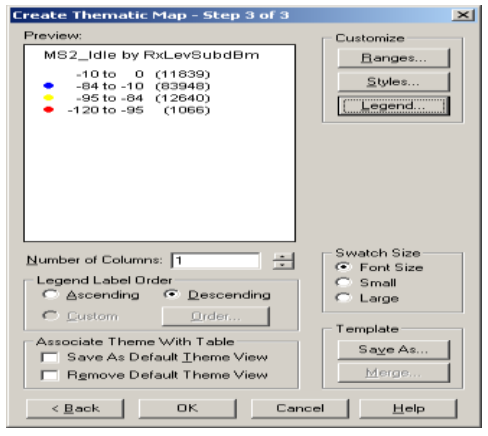

Gambar Legenda

5. Setelah selesai mengkonfigurasi legenda, selanjutnya adalah menyimpan template tersebut. Hasil dari thematic map yang telah dibuat terlihat pada gambar

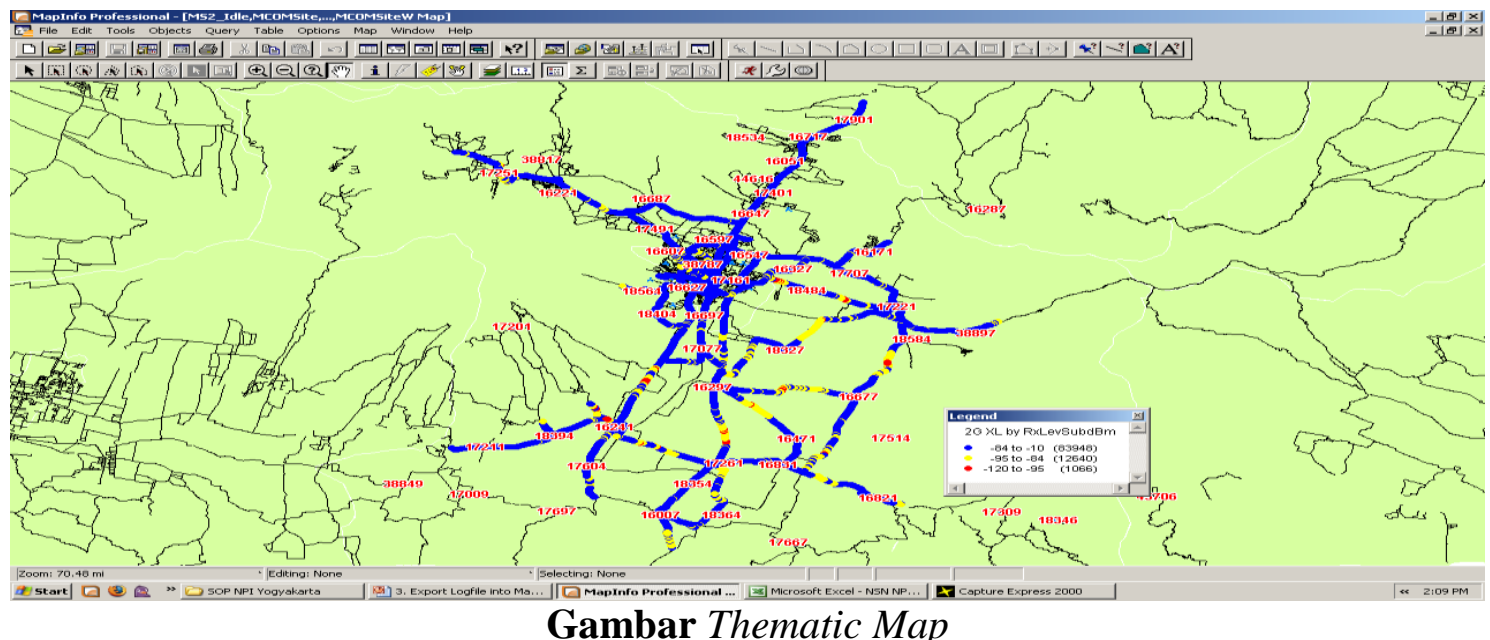

Gambar Thematic Map

Langkah-langkah di atas adalah cara untuk membuat thematic map yang memperlihatkan data-data yang ada melalui sebuah gambar. Selain melalui sebuah gambar, thematic map juga dapat menampilkan distribusi statistik dari data- data yang ada. Cara untuk menghitung statistik sama seperti membuat thematic map di atas. Hanya saja pada langkah pertama yang dipilih adalah menu "Individual". 


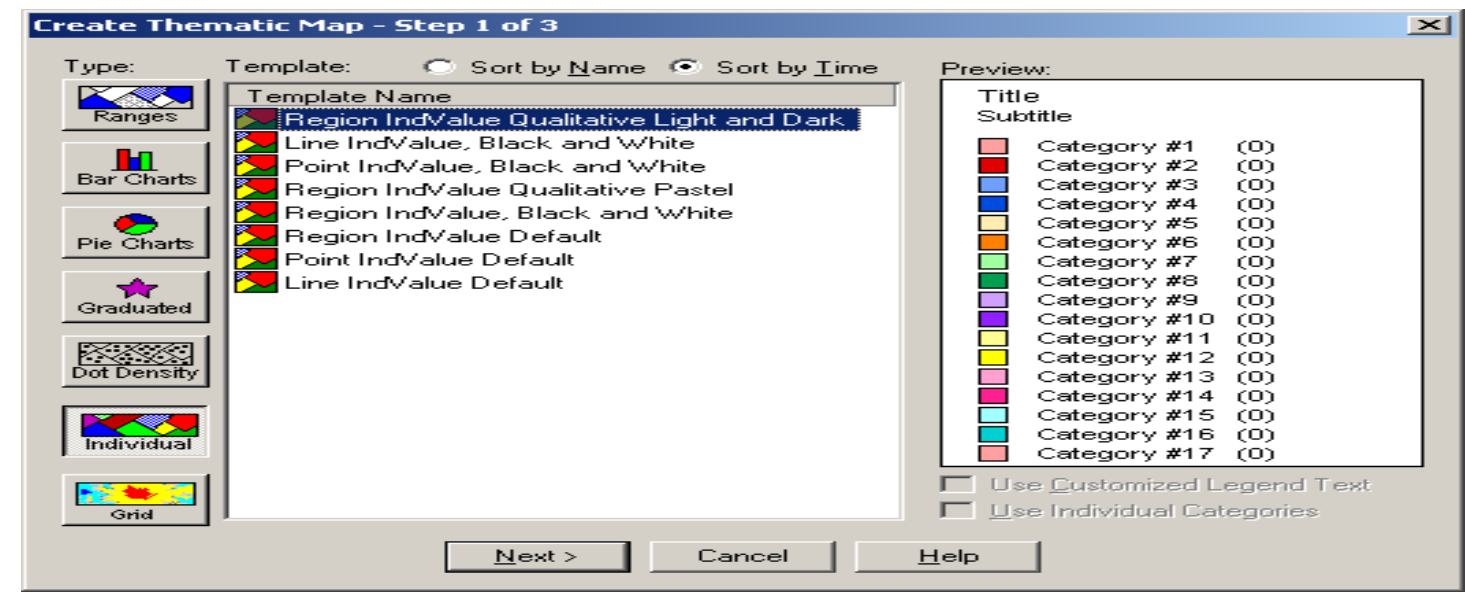

Gambar Individual

Setelah proses pembuatan data statistik selesai, maka hasil dari tampilan yang dikeluarkan terlihat pada gambar

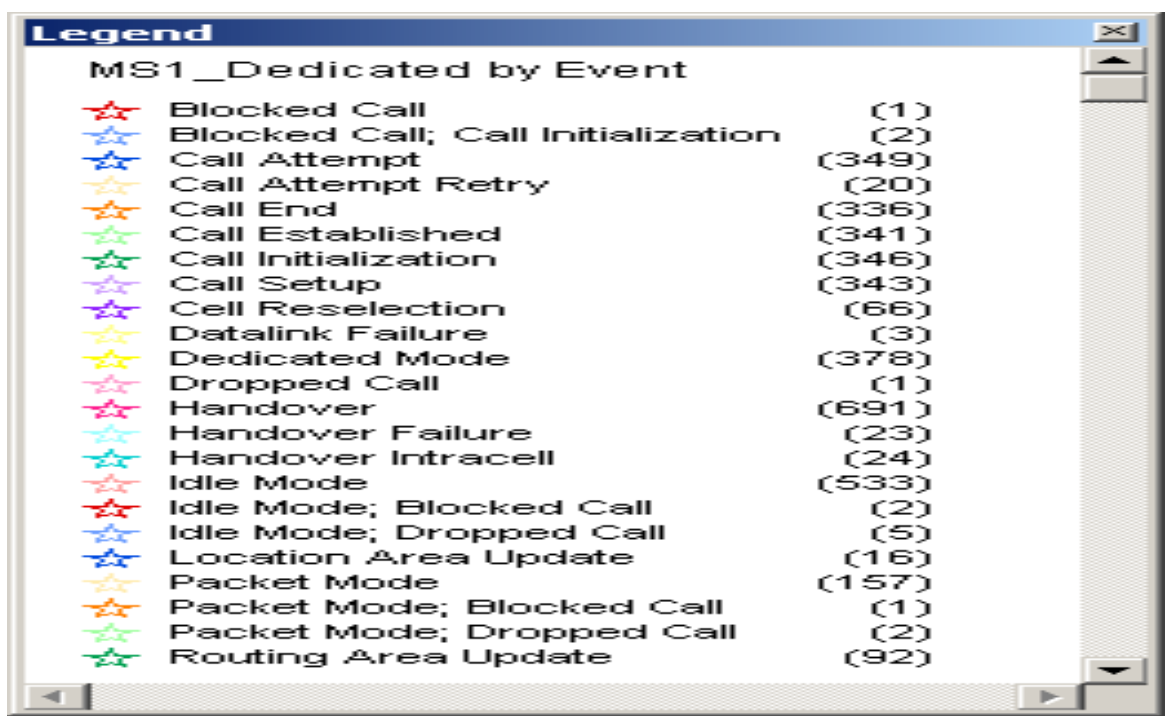

Gambar . Data Statistik

Dengan menggunakan software Mapinfo, data-data yang telah diambil menggunakan software TEMS dapat dilihat secara visual sehingga dapat lebih mudah untuk dianalisa. Namun bila ingin menganalisa lebih detil, maka setiap kejadian pada saat drive test dapat dilihat pada logfile yang telah tersimpan.
PENUTUP

\section{Kesimpulan}

1. Drive test dilakukan untuk mensimulasikan unjuk kerja suatu jaringan telekomunikasi dan mengambil data-data yang diperlukan sehingga dapat dilakukan optimisasi terhadap jaringan tersebut.

2. Dengan melakukan drive test maka pihak penyelenggara jaringan 
telekomunikasi dapat mengetahui kondisi jaringan yang sebenarnya.

3. Post processing setelah pelaksanaan drive test harus dilakukan dengan teliti, karena hasilnya akan digunakan untuk proses analisa kualitas jaringan.

\section{DAFTAR PUSTAKA}

1. Anshori,isa Modul Drive Test,Surabaya 2016

2. Misra ajay.R. Advanced Cellular Network,Plain and Optimisation,Jhon Wiley and Sons Ltd,England 2016
3. Internal,Ericsson,Introduction to RF Planning 2016

4. Hawking,Neville,GSM Radio Network Optimisation,Telcom Network Consultan Ltd 2016

5. http://lakemba.co.id

6. http://telecommunicationforall.blogs pot.com/2008/05/basic-drivetest.html

7. http://telecommunicationforall.blogs pot.com/2008/05/pengenalantems.html. 